
\title{
25 Research Square \\ CD137 agonist induces gastric cancer cell apoptosis by enhancing the functions of CD8+ T cells via NF-KB signaling
}

\section{Ben-Shun Hu}

Nanjing Medical University

Tian Tang

Nanjing Medical University

Tie-Long Wu

Jiangnan University

Ying-Yue Sheng

Jiangnan University

xue yuzheng ( $\nabla$ xueyz001@163.com )

Jiangnan University https://orcid.org/0000-0002-4218-9513

Primary research

Keywords: CD137, gastric cancer, CD8+ T cells, immune microenvironment

Posted Date: August 12th, 2020

DOI: https://doi.org/10.21203/rs.3.rs-56382/v1

License: (c) (1) This work is licensed under a Creative Commons Attribution 4.0 International License. Read Full License

Version of Record: A version of this preprint was published on October 20th, 2020. See the published version at https://doi.org/10.1186/s12935-020-01605-0. 


\section{Abstract}

Background: CD137 is a target for tumor immunotherapy. However, the role of CD137 in gastric cancer (GC), especially in inducing GC cell apoptosis, has not been studied.

Methods: Foxp $3^{+}$and $\mathrm{CD} 8^{+} \mathrm{T}$ cells in GCs were investigated using immunohistochemistry (IHC). CD137 expression in GCs was detected using flow cytometry, IHC and immunofluorescence (IF). Peripheral blood mononuclear cells (PBMCs) and $\mathrm{CD} 8^{+} \mathrm{T}$ cells isolated from peripheral blood were stimulated with a CD137 agonist in vitro. CD $8^{+} \mathrm{T}$ cell proliferation and p65 expression was examined using flow cytometry. P65 nuclear translocation was analyzed using IF. IL-10, TGF- $\beta$, IFN- $\gamma$, perforin and granzyme B were detected using real-time quantitative PCR (real-time PCR). PBMCs and primary GC cells were cocultured and stimulated with a CD137 agonist in vitro. Apoptosis of primary GC cells was detected using flow cytometry.

Results: Our data demonstrated that GC tumors showed characteristics of an immunosuppressive microenvironment. CD137 was predominantly expressed in $\mathrm{CD} 8^{+} \mathrm{T}$ cells in GCs and had a positive correlation with tumor cell differentiation. The CD137 agonist promoted CD $8^{+} \mathrm{T}$ cell proliferation and increased the secretion of IFN- $\gamma$, perforin and granzyme B, which induced primary GC cell apoptosis. Mechanistically, this study found that the CD137 agonist induced NF-KB nuclear translocation in CD8 ${ }^{+} \mathrm{T}$ cells.

Conclusion: Our results demonstrated that a CD137 agonist induced primary GC cell apoptosis by enhancing $\mathrm{CD} 8^{+} \mathrm{T}$ cells via activation of NF-KB signaling.

\section{Background}

Gastric cancer (GC) is a common malignant tumor. Chemotherapy and molecular-targeted therapy achieved limited improvements in survival[1,2]. Immunotherapy is a new method of tumor treatment in addition to surgery, chemotherapy and radiotherapy $[3,4]$. Vaccines activate the initial T lymphocyte reaction, and an immune checkpoint activator enhances the activity of $\mathrm{T}$ lymphocytes[5]. Adaptive immunotherapy achieved an antitumor effect via the reinfusion of tumor-specific effector lymphocytes expanded in vitro[6]. Immunosuppressive agents showed a certain effect in the treatment of GC, but immune checkpoint agonists are less studied in GC.

CD137, also known as 4-1BB, is a member of the tumor necrosis factor (TNF) receptor family, and it is encoded by the TNF receptor superfamily member 9 (TNFRSF9) gene[7, 8]. Mouse CD137 is located at $75.5 \mathrm{~cm}$ on mouse chromosome 4 , and it exhibits approximately $60 \%$ homology with human CD137[9]. CD137 is primarily expressed in activated $\mathrm{CD} 8^{+}$and $\mathrm{CD} 4^{+} \mathrm{T}$ cells and regulatory $\mathrm{T}$ cells (Tregs) $[10,11]$. Accumulated animal experiments demonstrated that mice with a systemic deletion of CD137 genes showed disordered immune homeostasis and lost the ability to fight against tumor immune memory. However, the role of CD137 in GC was not investigated[12]. 
CD137 expression is upregulated on antigen-presenting cells (APCs) as a result of the activation of T cells initiated by B7-1, B7-2 and antigenic peptides, which promote the production and secretion of cytokines via the activation of NF-KB[13, 14]. It is well established that CD137 induces TNFR-related factors TRAF1 and TRAF2 to form a heterotrimer, which activates mitogen-activated protein kinase (MAPK), $\beta$-catenin and AKT signaling and augments NF-KB nuclear translocation[15-17]. Notably, the activation of NF-KB contributes to the survival of $C D 8^{+} T$ lymphocytes by increasing the expression of the antiapoptotic genes Bcl-xL and bfl-I[11, 18]. However, whether CD137-mediated activation of NF-KB in $\mathrm{CD}^{+} \mathrm{T}$ lymphocytes induces $\mathrm{GC}$ cell apoptosis by enhancing the function of $\mathrm{CD} 8^{+} \mathrm{T}$ cells is not clear.

The most effective approach for CD137 agonist therapy is stimulation of the proliferation of CD8 ${ }^{+} \mathrm{T}$ cells by increasing the expression of IFN-y and several granzymes[19]. The CD137 costimulatory signal is activated by a CD137 agonist or CD137L transfection, which induces cell proliferation, cytokine expression and bactericidal activity and supports T cell effector function[20]. CD137 agonists also inhibit the differentiation of conventional effector cells into Tregs, negatively regulates the activity of Tregs, or maintains the expansion and inhibition of Tregs[21].

The present study demonstrated that GC tumors showed the characteristics of an immunosuppressive microenvironment. A CD137 agonist induced primary GC cell apoptosis by enhancing $\mathrm{CD} 8^{+} \mathrm{T}$ cells via activation of NF-KB signaling.

\section{Materials And Methods}

\section{Patients and specimens}

For phenotypic assays, 23 fresh gastric cancerous, tumor margin and tumor-free gastric tissues (greater

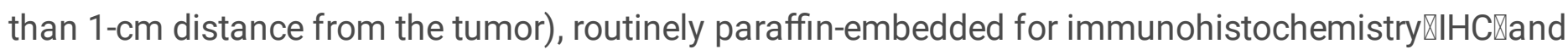
immunofluorescence $\mathrm{XIF \bigotimes}$, were collected from 23 patients with GC who underwent surgery at our hospital between May 2019 and May 2020. Twenty-three fresh gastric cancerous tissues, isolated of tumor infiltrating lymphocytes (TILs) for flow cytometry, were collected. The clinical characteristics of the patients for phenotypic assay are listed in Table 1.

For the functional assay, peripheral blood from 18 patients with GC was collected before surgery.

Eighteen fresh gastric cancerous tissues were collected during surgery. The clinical characteristics of the patients for functional assays are listed in Table 2.

None of the patients who provided samples received preoperative radiotherapy or chemotherapy and were confirmed to have GC on postoperative pathology. Informed consent for publication was obtained from all participants. The present study was performed in accordance with ethical standards and according to the declaration of the national and international guidelines, and the institutional review board of Jiangnan University approved the study.

\section{Antibodies and reagents}


RNAlater ${ }^{\circledR}$ was purchased from Ambion. TRIzol was purchased from Invitrogen. DEPC was purchased from Bio Basic Inc. The SYBR ${ }^{\circledR}$ PrimeScript ${ }^{\circledR}$ RT-PCR Kit was purchased from TaKaRa for two-step RTPCR. PCR primers were designed by TaKaRa and synthesized by Yingjun Biotechnology Co., Ltd. An antiCD137 rabbit mAb (\#34549) used for IHC and IF and was purchased Cell Signaling Technology (CST, USA). An IHC detection reagent (HRP, rabbit, \#8114) was purchased from CST. An agonistic anti-CD137 mAb (\#79097) was purchased from BPS Bioscience. An anti-Foxp3 rabbit mAb (\#12653) used for IHC was purchased from CST. Anti-CD8 mouse antibody (\#66868-1-lg) for IHC and IF was purchased from the Proteintech group. MojoSort ${ }^{\mathrm{TM}}$ Magnet, MojoSort ${ }^{\mathrm{TM}}$ Human CD8 Nanobeads and MojoSort ${ }^{\mathrm{TM}}$ Human CD8 Cell Isolation Kit were purchased from BioLegend. An NF-KB p65 rabbit mAb (\#8242) for flow cytometry and IF was purchased from CST. An anti-cytokeratin mouse mAb (\#ab756) used for IHC was purchased from Abcam. A purified anti-human CD3 mAb (OKT3, \#317326) for cell incubation and antiCD45-PerCP (\#368506), anti-CD3-FITC (\#300406), anti-CD8-APC (\#301014) and anti-CD137-APC (\#309809) antibodies for flow cytometry were purchased from BioLegend.

\section{IHC assay}

Fresh tissues or collected cells were fixed, dehydrated and paraffin embedded. Paraffin sections were dewaxed and rehydrated using a routine protocol. The cells underwent antigen repair, neutralization of endogenous catalases, serum blocking, incubation with anti-CD137 rabbit mAb antibody (1:100, CST), anti-Foxp3 rabbit mAb antibody (1:100, CST), anti-cytokeratin mouse mAb antibody (1:100, Abcam) and anti-CD8 mouse antibody (1:100, Proteintech group) at $4^{\circ} \mathrm{C}$ overnight. Cells were incubated with a secondary antibody, and DAB was used for color development. Cells were counterstained, neutral gum sealed and observed according to a standard immunohistochemical operation procedure. PBS was used as a negative control. The stained sections were scanned using Panoramic MIDI. Image $\mathrm{J}$ was used to count positively stained cells. Two senior pathologists independently confirmed the results.

\section{IF assay}

Paraffin sections of a specimen were dewaxed and sealed with $3 \% \mathrm{H}_{2} \mathrm{O}_{2}$ for 10 min and heat-retrieved with $0.01 \mathrm{mmol} / \mathrm{I}$ citrate buffer $(\mathrm{pH}=6.0)$. After natural cooling, the sections were blocked with goat serum for $30 \mathrm{~min}$ and incubated with an anti-CD137 rabbit mAb (1:100, CST) and anti-CD8 mouse mAb (1:100, Proteintech group) overnight in a water tank at $4{ }^{\circ} \mathrm{C}$. After $1 \mathrm{~h}$ of rewarming, antigens were detected with an anti-rabbit IgG $(\mathrm{H}+\mathrm{L}), \mathrm{F}(\mathrm{ab}) 2$ Fragment (Alexa Fluor ${ }^{\circledR} 594$ Conjugate) and anti-mouse Ig $\mathrm{G}(\mathrm{H}+\mathrm{L})$, $\mathrm{F}\left(\mathrm{ab}^{\prime}\right) 2$ Fragment (Alexa Fluor ${ }^{\circledR} 488$ Conjugate) (both 1:500, CST). The sections were incubated at $37{ }^{\circ} \mathrm{C}$ for $1 \mathrm{~h}$, and DAPI was added. The sections were incubated in the dark for $5 \mathrm{~min}$, sealed with $50 \%$ glycerol, and observed under a confocal microscope.

After slide preparation, cells for IF were fixed in $4 \%$ paraformaldehyde and penetrated using $0.5 \%$ Triton X100 at room temperature for $20 \mathrm{~min}$. The slides were blocked with goat serum for $30 \mathrm{~min}$ and incubated with an anti-NF-KB p65 rabbit mAb (1:100, CST) overnight in a water tank at $4{ }^{\circ} \mathrm{C}$. After $1 \mathrm{~h}$ of rewarming, the primary antibodies were detected using an anti-rabbit IgG $(\mathrm{H}+\mathrm{L}), \mathrm{F}\left(\mathrm{ab}\right.$ ')2 Fragment (Alexa Fluor ${ }^{\circledR} 594$ 
Conjugate) (1:500, CST) for $1 \mathrm{~h}$. DAPI was added, and the sections were incubated in the dark for 5 min. Stained sections were observed under a fluorescence microscope.

\section{Isolation of TILS}

Gastric cancerous tissue specimens were cut into 1-mm-diameter pieces using ophthalmic surgical scissors, and the appropriate amount of tissue digestive solution containing $2 \mathrm{mg} / \mathrm{ml}$ type IV collagenase and $0.25 \mathrm{mg} / \mathrm{ml}$ hyaluronidase was added. The samples were transferred to a $15-\mathrm{ml}$ centrifuge tube and digested in a shaker at $37^{\circ} \mathrm{C}$ for $30 \mathrm{~min}$. The cell suspension obtained from digestion was filtered with a $70-\mu \mathrm{m}$ sieve, and the filtered liquid was collected in a $50-\mathrm{ml}$ centrifuge tube. Ten milliliters of $40 \%$ Percoll was added, then $10 \mathrm{ml}$ of $80 \%$ Percoll was added below the $40 \%$ Percoll. The tubes were centrifuged at $2000 \mathrm{rpm}$ for $20 \mathrm{~min}$. TILs were isolated between the $40 \%$ Percoll and $80 \%$ Percoll.

\section{Isolation of PBMCs and $\mathrm{CD}^{+} \mathrm{T}$ cells}

After transferring $20 \mathrm{ml}$ of blood from patients with GC into 50-ml centrifuge tubes, $10 \mathrm{ml}$ of PBS was added to dilute the blood. The solution was mixed gently, and $10 \mathrm{ml}$ of Ficoll lymphocyte separation solution was added to the bottom of $50-\mathrm{ml}$ centrifuge tubes. Samples were centrifuged at $2000 \mathrm{rpm}$ for 20 min, and lymphocytes were collected and washed twice with PBS for 5 min each time. Isolated PBMCs were washed with MojoSort ${ }^{\mathrm{TM}}$ buffer once. The experimental procedure for CD8 isolation protocol was performed according to the MojoSort ${ }^{\mathrm{TM}}$ Human CD $8 \mathrm{~T}$ Cell Isolation Kit provided by BioLegend.

\section{Isolation of primary GC cells}

Live gastric cancerous specimens were immersed in sterilized PBS containing $200 \mathrm{U} / \mathrm{ml}$ penicillin and streptomycin for $10 \mathrm{~min}$, then washed with sterilized PBS containing $1000 \mathrm{U} / \mathrm{ml}$ penicillin and streptomycin 5 times. The specimens were immersed in sterilized PBS containing $200 \mathrm{U} / \mathrm{ml}$ penicillin and streptomycin for $10 \mathrm{~min}$ to remove blood and bacteria on the surface of the specimens. The tissue specimens were cut into 1-mm-diameter pieces using ophthalmic surgical scissors, and the appropriate amount of tissue digestive solution containing $2 \mathrm{mg} / \mathrm{ml}$ type IV collagenase and $0.25 \mathrm{mg} / \mathrm{ml}$ hyaluronidase was added. The samples were transferred to a $15-\mathrm{ml}$ centrifuge tube And digested in a shaker at $37{ }^{\circ} \mathrm{C}$ for $30 \mathrm{~min}$. The cell suspension obtained from digestion was filtered with a $70-\mu \mathrm{m}$ sieve, and the filtered liquid was collected in a 50-ml centrifuge tube. Ten milliliters of Ficoll lymphocyte separation solution was added to the bottom of $50-\mathrm{ml}$ centrifuge tubes, and the tubes were centrifuged at $2000 \mathrm{rpm}$ for $20 \mathrm{~min}$ for lymphocyte removal. Cells at the bottom of $50-\mathrm{ml}$ centrifuge tubes were collected, and erythrocyte lysate was added for $10 \mathrm{~min}$ to remove red cells. The cells were washed with sterile PBS containing $1000 \mathrm{U} / \mathrm{ml}$ penicillin and streptomycin 5 times.

\section{Primary GC cells and CD8 ${ }^{+} \mathrm{T}$ cells stained with CFSE}

Primary GC cells and $C D 8^{+} T$ cells were collected and washed with PBS 3 times for 5 min each wash. Primary GC cells were treated with $1 \mathrm{ml}$ of $5 \mu \mathrm{M} \mathrm{CFSE}$ and cultured in a $37^{\circ} \mathrm{C} \mathrm{CO}_{2}$ incubator for $15 \mathrm{~min}$. 
One milliliter of fetal bovine serum was added to stop the staining for 1 minute, and the cells were washed twice with PBS.

\section{Cell culture}

CFSE-labeled $\mathrm{CD}^{+}{ }^{+} \mathrm{T}$ cells, PBMCs or/and CFSE-labeled primary GC cells isolated from GC patients were added to 96 -well plates coated with a purified anti-human CD3 antibody at $5 \mu \mathrm{g} / \mathrm{ml}$ overnight to upregulate CD137 expression and cultured in DMEM with 10\% FBS.

\section{Flow cytometry}

For CD137 detection, the PBMCs or TILs of GC patients were placed in flow tubes, and $5 \mu \mathrm{L}$ each of an anti-CD45-PerCP antibody, anti-CD3-FITC antibody and anti-CD137-APC antibody was added. The cells were incubated in the dark for 10 min and washed with PBS once. PBS $(200 \mu \mathrm{L})$ was added for flow cytometry detection.

For examination of $C D 8^{+} T$ cells proliferation, $C D 8^{+} T$ cells of GC patients were placed in flow tubes and washed once with PBS. PBS $(200 \mu \mathrm{L})$ was added for flow cytometry detection.

For NF-KB detection, CD $8^{+} \mathrm{T}$ cells from GC patients were treated with $10 \mu \mathrm{g} / \mathrm{ml}$ anti-CD137 mAb for $72 \mathrm{~h}$ and placed in flow tubes. After washing once with PBS, a Fixation/Permeabilization Solution (BD Cytofix/Cytoperm ${ }^{\mathrm{TM}}$ ) was added at room temperature for $30 \mathrm{~min}$. After washing once with PBS, an NF-KB p65 rabbit mAb (1:1000, CST) was added. The cells were incubated in the dark for $1 \mathrm{~h}$ and washed once with PBS. Five microliters of anti-rabbit IgG $(\mathrm{H}+\mathrm{L}), \mathrm{F}\left(\mathrm{ab} \mathrm{b}^{\prime}\right) 2$ Fragment (Alexa Fluor ${ }^{\circledR} 594$ Conjugate) (1:500, CST) was added, and the cells were incubated in the dark for $30 \mathrm{~min}$. After washing once with PBS, 200 $\mu \mathrm{L}$ of PBS was added for flow cytometry detection.

\section{Primary GC cell apoptosis detection using flow cytometry}

PBMCs $\left(1 \times 10^{5}\right)$ and primary GC cells $\left(2 \times 10^{4}\right.$, CFSE stained) were mixed, placed in anti-human CD3 antibody-coated 96-well plates containing $200 \mu \mathrm{l}$ of $10 \%$ FBS DMEM, and treated with $10 \mu \mathrm{g} / \mathrm{ml}$ antiCD137 mAb. Apoptosis in the GC cells was detected using flow cytometry after $72 \mathrm{~h}$.

\section{RNA extraction and reverse transcription}

The TRIzol method was used to extract total RNA from cultured cells for RNA quantitative analysis and RNA electrophoresis. The conditions of the reverse transcriptase reaction were $42{ }^{\circ} \mathrm{C}$ for $15 \mathrm{~min}$ and inactivation of the reverse transcriptase at $95^{\circ} \mathrm{C}$ for $2 \mathrm{~min}$. A reverse transcriptase solution was added to a real-time PCR system. The reaction solution was stored at $-20^{\circ} \mathrm{C}$ until used. The DNA concentration was estimated from the A260/A280 value detected using a spectrophotometer.

Based on the cDNA sequences of IL-10, TGF- $\beta$, IFN- $\gamma$, perforin, granzyme $B$ and the housekeeping gene $\beta$ actin, real-time fluorescent quantitative PCR oligonucleotide primers were designed using Primer Premier 
5 software. BLAST was used to confirm the specificity of sequences. The primer sequences were designed and synthesized using TaKaRa. Primers for specific genes in this study are listed in Table 3. For real-time PCR amplification, sample analysis was performed as follows: each group contained three duplicate detection tubes; each sample was evenly mixed, centrifuged, tested using a computer, and amplified via fluorescence quantitative PCR to produce an amplification curve. The following reaction process was used: predenaturation at $95^{\circ} \mathrm{C}$ for $5 \mathrm{~min}$, denaturation at $95^{\circ} \mathrm{C}$ for $15 \mathrm{~s}$, annealing at $58{ }^{\circ} \mathrm{C}$ for $15 \mathrm{~s}$, and elongation at $72{ }^{\circ} \mathrm{C}$ for $40 \mathrm{~s}$ (40 cycles). The corresponding software program of the realtime PCR instrument used recorded and analyzed the detection data and output the results. The relative expression of each target gene was calculated using the $2^{-\triangle \Delta C T}$ method, and amplification of the target gene was compared between each experimental group and the control group.

\section{Statistical analysis}

Statistical analyses were performed using GraphPad Prism 6 software. All data are shown as means \pm standard error of the mean (SEM). An unpaired two-tailed Student's $t$ test was used for comparisons between two groups. One-way ANOVA was used for multiple comparisons. Significant $p$-values are labeled with one or more ' ${ }^{\prime \prime}$, denoting ${ }^{\star} \mathrm{p}<.05,{ }^{\star \star} \mathrm{p}<.01,{ }^{\star \star \star} \mathrm{p}<.001$ and ${ }^{\star \star \star \star} \mathrm{p}<.0001$. A threshold of $\mathrm{P}<$ 0.05 was defined as statistically significant.

\section{Results}

\section{Poor infiltration of $\mathrm{CD}^{+} \mathrm{T}$ cells but accumulation of Tregs in GCs}

To compare the composition of $\mathrm{CD} 8^{+}$and Treg cells in the tumor tissues, tumor-free tissues and tumor margin tissues of GC patients, we analyzed the proportions of $\mathrm{CD} 8^{+} \mathrm{T}$ cells and Foxp3 ${ }^{+}$Tregs using IHC. Foxp $3^{+}$Tregs accumulated in the tumor (Fig. $1 \mathrm{~A}$ and B), but most $\mathrm{CD} 8^{+} \mathrm{T}$ cells sequestered at the tumor margin and in tumor-free tissues (Fig. $1 \mathrm{C}$ and D). These data suggested that CD $8^{+} \mathrm{T}$ cells were excluded from the tumors, and Foxp3 ${ }^{+}$Tregs infiltrated into the tumors of GC patients.

\section{CD137 was highly expressed in differentiated tumor and primarily expressed in CD8 ${ }^{+} \mathrm{T}$ cells in GCs}

To analyze CD137 expression in GCs, we first examined CD137 expression in TILs of GC patients. Notably, CD137 was highly expressed in differentiated tumor (Fig. 2 A and B). This result was confirmed using IHC and IF (Fig. 2 C and D). IF showed that CD137 was primarily expressed in CD8 ${ }^{+}$TILs (Fig. 3 A). Therefore, we focused on the function of $\mathrm{CD} 137$ on $\mathrm{CD} 8^{+} \mathrm{T}$ cells.

\section{An agonistic anti-CD137 mAb enhanced $\mathrm{CD}^{+} \mathrm{T}$ cell proliferation and increased the secretion of IFN- $\gamma$, perforin and granzyme B, but had little effect on Tregs in GC}

To determine the role of $\mathrm{CD} 137$ in the immune microenvironment of $\mathrm{GC}, \mathrm{CD} 8^{+} \mathrm{T}$ cells were isolated from peripheral blood of GC patients (Fig. 3 B, C, D and E) and stimulated with a CD137 agonist. The 
proliferation of CFSE-labeled $\mathrm{CD}^{+} \mathrm{T}$ cells was observed in the presence of an agonistic anti-CD137 mAb (Fig. $3 \mathbf{F}$ and $\mathbf{G}$ ). We examined the overall effect of the CD137 agonist in GC patients. PBMCs were isolated from peripheral blood of GC patients. For Tregs, the secretion of IL-10 and TGF- $\beta$ plays a role in maintaining immune tolerance. IL-10 and TGF- $\beta$ were detected using real-time PCR. Our results showed that IL-10 and TGF- $\beta$ levels were almost unchanged in the presence of a CD137 agonist (Fig. 4 A and B). Notably, the CD137 agonist increased the production of IFN-y, perforin and granzyme B (Fig. 4 C, D and E) and secretion from $\mathrm{CD}^{+} \mathrm{T}$ cells in the PBMCs from GC patients. Taken together, these results demonstrated that the function of $\mathrm{CD}^{+} \mathrm{T}$ cells was enhanced in the presence of a CD137 agonist.

\section{NF-KB expression and nuclear translocation increased in CD8 ${ }^{+} \mathrm{T}$ cells after CD137 agonist treatment}

To examine the mechanism of CD137 in CD8 ${ }^{+} \mathrm{T}$ cells, NF-kB subunit p65 expression and nuclear translocation were detected. $\mathrm{P} 65$ expression increased significantly in $\mathrm{CD} 8^{+} \mathrm{T}$ cells in the presence of a CD137 agonist (Fig. 5 A and B). The CD137 agonist also induced p65 nuclear translocation in $\mathrm{CD} 8^{+} \mathrm{T}$ cells (Fig. 5 C).

\section{A CD137 agonist induced apoptosis in primary GC cells}

We investigated the effect of the CD137 agonist on primary GC cells. HE staining combined with IHC \cytokeratin antibody to confirm tumors $₫$ was used to examine the purity of primary GC cells after isolation (Fig. 6 A, B and C). To further study the function of the CD137 agonist in the immune microenvironment of GC, we cocultured PBMCs and CFSE-labeled primary GC cells at a ratio of 5:1 in vitro in the presence of $10 \mu \mathrm{g} / \mathrm{ml}$ of the agonistic anti-CD137 mAb. Flow cytometry was used to detect primary GC cell apoptosis after $72 \mathrm{~h}$. Compared to control treatment, the CD137 agonist induced apoptosis in the primary GC cells (Fig. 6 D and E).

\section{Discussion}

The morbidity and mortality of GC are high compared to other malignant tumors, and the clinical therapeutic effect of monoclonal antibodies against a single target in GC is limited[6, 22, 23]. To improve the curative effect and reduce drug resistance, the identification of specific monoclonal antibodies for the treatment for GC is urgent[24, 25]. Immune escape is an important process of tumor development. We also found that the immunosuppressive microenvironment excluded $\mathrm{CD} 8^{+} \mathrm{T}$ cells from the tumors, but Foxp $3^{+}$Tregs infiltrated into the tumors of GC patients. CD137/CD137L targeted therapy is effective against melanoma, leukemia and other tumors[26]. The present study examined the effects of CD137 on the immune microenvironment of GC to provide new ideas for treatment.

We demonstrated that CD137/CD137L activation signaling promoted the activation and proliferation of tumor-specific T cells, increased the secretion of cytokines, and protected T cells from activation-induced cell death[27, 28]. The intraperitoneal administration of an anti-CD137 monoclonal antibody eliminated tumors that were established via subcutaneous inoculation of Agl04A sarcoma or 10815 mast cells in 
mice on the third and seventh day after inoculation, respectively[24]. The enhanced immune response was primarily mediated by $\mathrm{CD} 8^{+} \mathrm{T}$ cells that were activated by the anti-CD137 monoclonal antibody and accompanied by a significant enhancement in tumor-specific cytotoxic T lymphocyte (CTLs) activity[29]. For $\mathrm{CD} 4^{+} \mathrm{T}$ cells, CD137/CD137L signal transduction induces cell expansion but does not prolong cell survival[30]. CD137 is primarily expressed on the surface of activated T cells, and our study found that CD137 was predominantly expressed on the surface of $\mathrm{CD} 8^{+} \mathrm{T}$ cells in the GC immune microenvironment and may positively correlate with tumor differentiation.

CD137 has a more restricted number of TRAF family members involved in its regulation, and only TRAF1, TRAF2, and TRAF3 interact with and control CD137 activity[31]. Recruitment of the CD137 signalosome by K63-polyubiquitinated TRAF2 is a kinase complex composed of transforming growth factor betaactivated kinase (TAK)-1, which phosphorylates the inhibitor of nuclear factor $K-B$ kinase (IKK)- $\beta$ and leads to the activation of canonical NF-KB[32]. Our results showed that a CD137 agonist enhanced CD8 ${ }^{+}$ T cell proliferation. A CD137 agonist also increased p65 expression and induced p65 nuclear translocation in $\mathrm{CD} 8^{+} \mathrm{T}$ cells. IL-10 and TGF- $\beta$ secretion from Tregs plays a critical role in maintaining immune tolerance. Therefore, we examined the effects of a CD137 agonist on Tregs. Our data suggested that the CD137 agonist increased the secretion of IFN- - , perforin and granzyme $B$ in the $C D 8^{+} \mathrm{T}$ cells but had little effect on Tregs in the PBMCs from GC patients. The CD137 agonist significantly induced apoptosis in cocultured primary PBMCs and primary GC cells, which suggests that a CD137 agonist is an adaptor in the immune microenvironment of GC.

\section{Conclusions}

CD8 ${ }^{+} \mathrm{T}$ cells were excluded from tumors, and Foxp $3^{+}$Tregs infiltrated into the tumors in GC patients. CD137 was primarily expressed on CD8-positive T cells in the GC immune microenvironment. A CD137 agonist enhanced $C D 8^{+} T$ cells proliferation via NF-KB signaling and increased the secretion of IFN- $\gamma$, perforin and granzyme B but had little effect on Tregs in GC. A CD137 agonist induced apoptosis in primary GC cells. This study provides new ideas for the treatment of GC and has potential translational value.

\section{Abbreviations}

GC: gastric cancer; IHC: immunohistochemistry; IF: immunofluorescence; PBMCs: peripheral blood mononuclear cells; Real-time PCR: real-time quantitative PCR; TILs: tumor infiltrating lymphocytes; TNF: tumor necrosis factor; TNFRSF9: TNF receptor superfamily member 9; Tregs: regulatory T cells; APCs: antigen-presenting cells; DCs: dendritic cells; JNK: c-Jun N-terminal kinase; ERK: extracellular signal regulated kinase; CTLs: tumor-specific cytotoxic T lymphocytes.

\section{Declarations}




\section{Acknowledgments}

Not applicable.

\section{Author Contributions}

Ben-Shun Hu, and Yu-Zheng Xue conceived the study and designed the experiments; Ben-Shun Hu performed in vitro experiments; Tian Tang performed immunohistochemical staining and immunofluorescence; Yin-Yue Sheng and Tie-Long Wu organized the clinical samples and analyzed the data; Ben-Shun Hu wrote the manuscript; Yu-Zheng Xue modified the manuscript. All authors read and approved the final manuscript.

\section{Funding}

This study was supported by the Postgraduate Research \& Practice Innovation Program of Jiangsu Province (KYCX19_1123), Wuxi City Health and Health Committee Youth Project (Q201919), Top Talents Project of the "Six-one Project" for High-level Health Talents in Jiangsu Province (LGY2018016), Application and Translation of Key Techniques on Gastrointestinal Lubricant (ZM008), and Key Talents Project of "Strengthening Health through Science and Education" of Wuxi Health and Family Planning Commission (ZDRC039). This study is also a Wuxi Science and Technology Development Medical and Health Guidance Plan.

\section{Availability of data and material}

Data and materials are available for sharing if needed.

\section{Ethics approval and consent to participate}

This study has been conducted in accordance with ethical standards and according to the Declaration of the national and international guidelines, and has been approved by the authors' institutional review board. The study protocol was approved by the Medical Ethics Committee of Jiangnan University.

\section{Consent for publication}

Informed consent for publication was obtained from all participants.

\section{Competing interests}

The authors declare that they have no competing interests.

\section{References}

1. Arai H, Nakajima TE: Recent Developments of Systemic Chemotherapy for Gastric Cancer. Cancers (Basel) 2020, 12(5). 
2. Xu W, Yang Z, Lu N: Molecular targeted therapy for the treatment of gastric cancer. J. Exp. Clin. Cancer Res 2016, 04;35

3. Abdul-Latif M, Townsend K, Dearman C, Shiu KK, Khan K: Immunotherapy in gastrointestinal cancer: The current scenario and future perspectives. Cancer Treat Rev 2020, 88:102030.

4. Tan S, Xia L, Yi P, Han Y, Tang L, Pan Q, Tian Y, Rao S, Oyang L, Liang J et al: Exosomal miRNAs in tumor microenvironment. J Exp Clin Cancer Res 2020, 39(1):67.

5. Kono K, Nakajima S, Mimura K: Current status of immune checkpoint inhibitors for gastric cancer. Gastric Cancer 2020, 23(4):565-578.

6. Jones JO, Smyth EC: Gastroesophageal cancer: Navigating the immune and genetic terrain to improve clinical outcomes. Cancer Treat Rev 2020, 84:101950.

7. Wong HY, Schwarz H: CD137 / CD137 ligand signaling regulates the immune balance: A potential target for novel immunotherapy of autoimmune diseases. J Autoimmun 2020:102499.

8. Kang SW, Lee SC, Park SH, Kim J, Kim HH, Lee HW, Seo SK, Kwon BS, Cho HR, Kwon B: Anti-CD137 Suppresses Tumor Growth by Blocking Reverse Signaling by CD137 Ligand. Cancer Res 2017, 77(21):5989-6000.

9. Cannons JL, Chamberlain G, Howson J, Smink LJ, Todd JA, Peterson LB, Wicker LS, Watts TH: Genetic and functional association of the immune signaling molecule 4-1BB (CD137/TNFRSF9) with type 1 diabetes. J Autoimmun 2005, 25(1):13-20.

10. Lee SW, Vella AT, Kwon BS, Croft M: Enhanced CD4 T cell responsiveness in the absence of 4-1BB. J Immunol 2005, 174(11):6803-6808.

11. Sabbagh L, Pulle G, Liu Y, Tsitsikov EN, Watts TH: ERK-dependent Bim modulation downstream of the 4-1BB-TRAF1 signaling axis is a critical mediator of CD8 T cell survival in vivo. J Immunol 2008, 180(12):8093-8101.

12. Sabbagh L, Andreeva D, Laramee GD, Oussa NA, Lew D, Bisson N, Soumounou Y, Pawson T, Watts TH: Leukocyte-specific protein 1 links TNF receptor-associated factor 1 to survival signaling downstream of 4-1BB in T cells. J Leukoc Biol 2013, 93(5):713-721.

13. Kotanides H, Sattler RM, Lebron MB, Carpenito C, Shen J, Li J, Surguladze D, Haidar JN, Burns C, Shen L et al: Characterization of 7A5: A Human CD137 (4-1BB) Receptor Binding Monoclonal Antibody with Differential Agonist Properties That Promotes Antitumor Immunity. Mol Cancer Ther 2020, 19(4):988-998.

14. Shedlock DJ, Whitmire JK, Tan J, MacDonald AS, Ahmed R, Shen H: Role of CD4 T cell help and costimulation in CD8 T cell responses during Listeria monocytogenes infection. J Immunol 2003, 170(4):2053-2063.

15. Li G, Wu X, Zhang F, Li X, Sun B, Yu Y, Yin A, Deng L, Yin J, Wang X: Triple expression of B7-1, B7-2 and 4-1BBL enhanced antitumor immune response against mouse $\mathrm{H} 22$ hepatocellular carcinoma. $J$ Cancer Res Clin Oncol 2011, 137(4):695-703.

16. Serghides L, Bukczynski J, Wen T, Wang C, Routy JP, Boulassel MR, Sekaly RP, Ostrowski M, Bernard NF, Watts TH: Evaluation of OX40 ligand as a costimulator of human antiviral memory CD8 T cell 
responses: comparison with B7.1 and 4-1BBL. J Immunol 2005, 175(10):6368-6377.

17. Arron JR, Pewzner-Jung Y, Walsh MC, Kobayashi T, Choi Y: Regulation of the subcellular localization of tumor necrosis factor receptor-associated factor (TRAF)2 by TRAF1 reveals mechanisms of TRAF2 signaling. J Exp Med 2002, 196(7):923-934.

18. McPherson AJ, Snell LM, Mak TW, Watts TH: Opposing roles for TRAF1 in the alternative versus classical NF-kappaB pathway in T cells. J Biol Chem 2012, 287(27):23010-23019.

19. ZT F, TR N, DH H, RJ J, JJ E, MJ S, CM K, RY L, J Z, A G et al: A conserved intratumoral regulatory T cell signature identifies 4-1BB as a pan-cancer target. J Clin Invest 2020, 130(3):1405-1416.

20. Hodge G, Hodge S, Reynolds PN, Holmes M: Targeting peripheral blood pro-inflammatory CD28null T cells and natural killer T-like cells by inhibiting CD137 expression: possible relevance to treatment of bronchiolitis obliterans syndrome. J Heart Lung Transplant 2013, 32(11):1081-1089.

21. Smith SE, Hoelzinger DB, Dominguez AL, Van Snick J, Lustgarten J: Signals through 4-1BB inhibit T regulatory cells by blocking IL-9 production enhancing antitumor responses. Cancer Immunol Immunother 2011, 60(12):1775-1787.

22. Xu J, Zhang Y, Jia R, Yue C, Chang L, Liu R, Zhang G, Zhao C, Zhang Y, Chen C, Wang Y: Anti-PD-1 Antibody SHR-1210 Combined with Apatinib for Advanced Hepatocellular Carcinoma, Gastric, or Esophagogastric Junction Cancer: An Open-label, Dose Escalation and Expansion Study. Clin. Cancer Res 2019, 25(2) :515-523

23. Rocken C: Molecular classification of gastric cancer. Expert Rev Mol Diagn 2017, 17(3):293-301.

24. Ju SA, Lee SC, Kwon TH, Heo SK, Park SM, Paek HN, Suh JH, Cho HR, Kwon B, Kwon BS et al: Immunity to melanoma mediated by $4-1 \mathrm{BB}$ is associated with enhanced activity of tumourinfiltrating lymphocytes. Immunol Cell Biol 2005, 83(4):344-351.

25. Zhou G, Sprengers D, Mancham S, Erkens R, Boor PPC, van Beek AA, Doukas M, Noordam L, Campos Carrascosa L, de Ruiter $V$ et al: Reduction of immunosuppressive tumor microenvironment in cholangiocarcinoma by ex vivo targeting immune checkpoint molecules. J Hepatol 2019, 71(4):753762.

26. Sanchez-Paulete AR, Labiano S, Rodriguez-Ruiz ME, Azpilikueta A, Etxeberria I, Bolanos E, Lang V, Rodriguez M, Aznar MA, Jure-Kunkel M et al: Deciphering CD137 (4-1BB) signaling in T-cell costimulation for translation into successful cancer immunotherapy. Eur J Immunol 2016, 46(3):513522.

27. MC SR, RA T, S B, HZ Q, AT H, AT V, Immunology AAJ, biology c: CD134/CD137 dual costimulationelicited IFN-y maximizes effector T-cell function but limits Treg expansion. Immunol Cell Biol 2013, 91(2):173-183.

28. Yang J, Park OJ, Lee YJ, Jung HM, Woo KM, Choi Y: The 4-1BB ligand and 4-1BB expressed on osteoclast precursors enhance RANKL-induced osteoclastogenesis via bi-directional signaling. Eur J Immunol 2008, 38(6):1598-1609.

29. J D, A P, C A, A A, MC O, A R, I M-F, A T, P B, A LB et al: Intratumoral injection of interferon-a and systemic delivery of agonist anti-CD137 monoclonal antibodies synergize for immunotherapy. Int $J$ 
Cancer 2011, 128(1):105-118.

30. Woroniecka KI, Rhodin KE, Dechant C, Cui X, Chongsathidkiet P, Wilkinson D, Waibl-Polania J, Sanchez-Perez L, Fecci PE: 4-1BB Agonism Averts TIL Exhaustion and Licenses PD-1 Blockade in Glioblastoma and Other Intracranial Cancers. Clin Cancer Res 2020, 26(6):1349-1358.

31. Zapata JM, Perez-Chacon G, Carr-Baena P, Martinez-Forero I, Azpilikueta A, Otano I, Melero I: CD137 (4-1BB) Signalosome: Complexity Is a Matter of TRAFs. Front Immunol 2018, 9:2618.

32. Li G, Boucher JC, Kotani H, Park K, Zhang Y, Shrestha B, Wang X, Guan L, Beatty N, Abate-Daga D et al: 4-1BB enhancement of CAR T function requires NF-kappaB and TRAFs. JCI Insight 2018, 3(18).

\section{Tables}

Table 1: Characteristics of patients for phenotypic data

\begin{tabular}{|ll|}
\hline & GC(23) \\
\hline Sex(femal/male) & $14 / 9$ \\
\hline Age(years)** & $58.2 \pm 3.6$ \\
\hline Histopathology & Highly differentiated GC=6 \\
& Poorly differentiated GC $=17$ \\
\hline
\end{tabular}

GC, gastric cancer. **Mean \pm standard error of the mean.

Table 2: Characteristics of patients for functional data

\begin{tabular}{|ll|}
\hline & $\mathrm{GC}(18)$ \\
\hline Sex(femal/male) & $7 / 11$ \\
\hline Age(years) ${ }^{\star \star}$ & $65.2 \pm 3.1$ \\
\hline Histopathology & Highly differentiated GC=5 \\
& Poorly differentiated GC $=13$ \\
\hline
\end{tabular}

GC, gastric cancer. ${ }^{*}$ Mean \pm standard error of the mean.

Table 3: Real-time PCR primers description 


\begin{tabular}{|lll|}
\hline Gene & Primer sequence & \\
\hline & Forward $\left(5^{\prime}\right.$-3 $\left.^{\prime}\right)$ & Reverse $\left(5^{\prime}\right.$ - $\left.^{\prime}{ }^{\prime}\right)$ \\
\hline$\beta$-actin & TGGCACCCAGCACAATGAA & CTAAGTCATAGTCCGCCTAGAAGCA \\
\hline IL-10 & GACTTTAAGGGTTACCTGGGTTG & TCACATGCGCCTTGATGTCTG \\
\hline TGF- $\beta$ & ACTTGCACCACCTTGGACTTC & GGTCATCACCGTTGGCTCA \\
\hline IFN-y & TCGGTAACTGACTTGAATGTCCA & TCGCTTCCCTGTTTTAGCTGC \\
\hline Perforin & CGCCTACCTCAGGCTTATCTC & CCTCGACAGTCAGGCAGTC \\
\hline Granzyme B & TGGGGGACCCAGAGATTAAAA & TTTCGTCCATAGGAGACAATGC \\
\hline
\end{tabular}

Figures

A

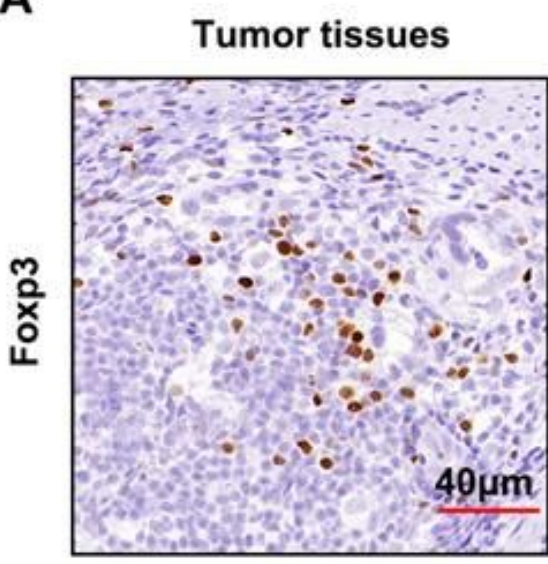

C

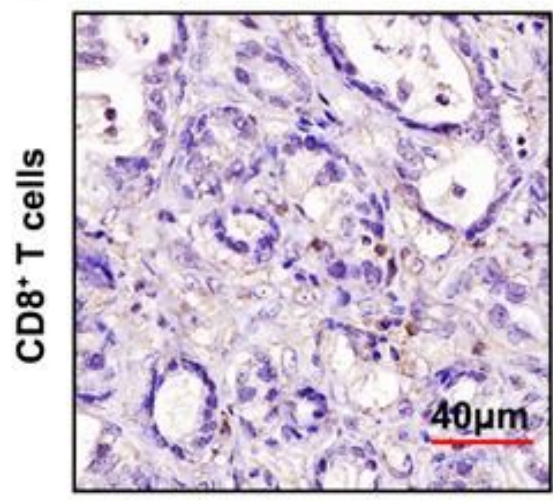

Tumor margin tissues

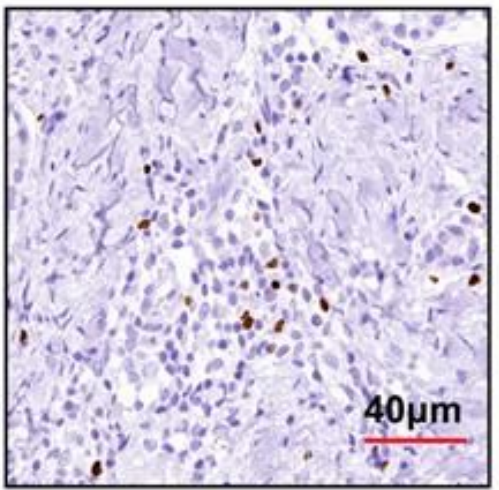

Tumor margin tissues

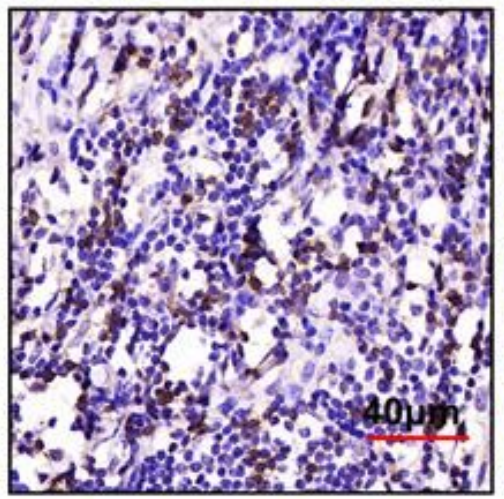

Tumor-free tissues

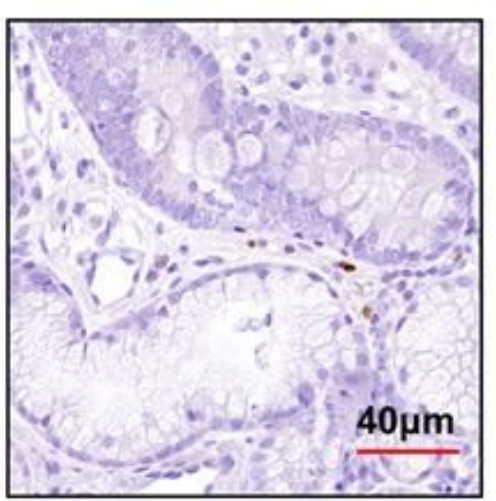

Tumor-free tissues

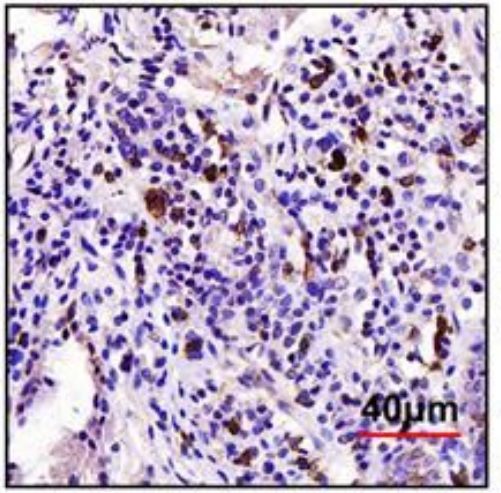

B

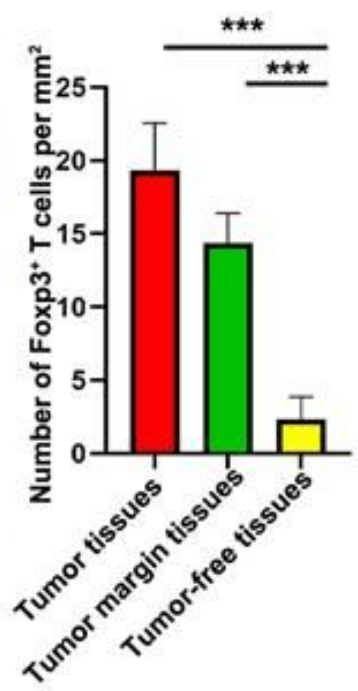

D

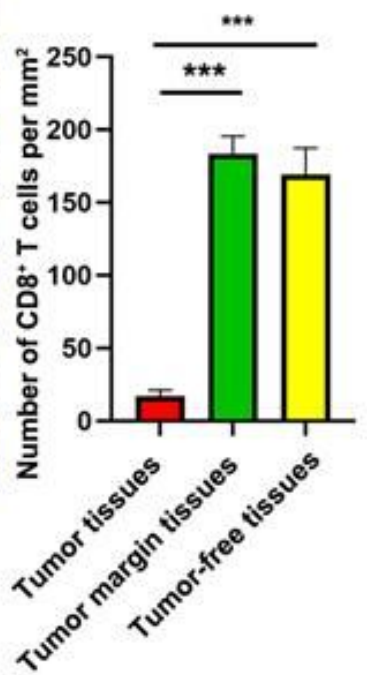


Poor infiltration of CD8+ T cells, but accumulation of Tregs, in GC. A, Foxp3 expression the GCs was detected using IHC. B, The cell densities of Foxp3 are depicted per square millimeter. Values are means with standard error of the mean. C, CD8 expression of GCs was detected using IHC. D, The cell densities of $\mathrm{CD} 8$ are depicted per square millimeter. Values are means with standard error of the mean.

A Poorly differentiated GC

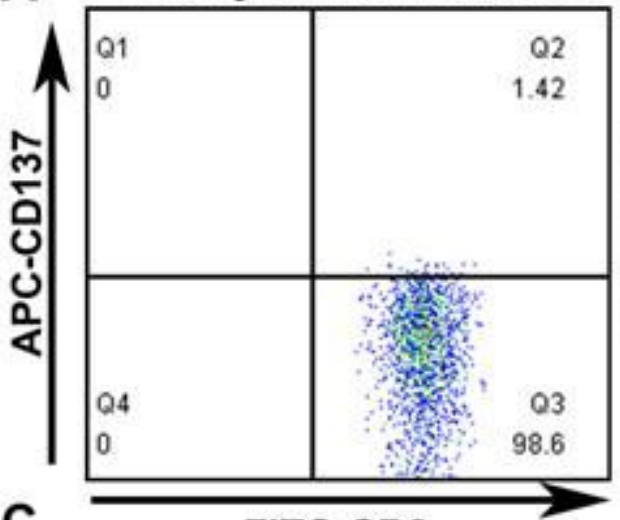

C

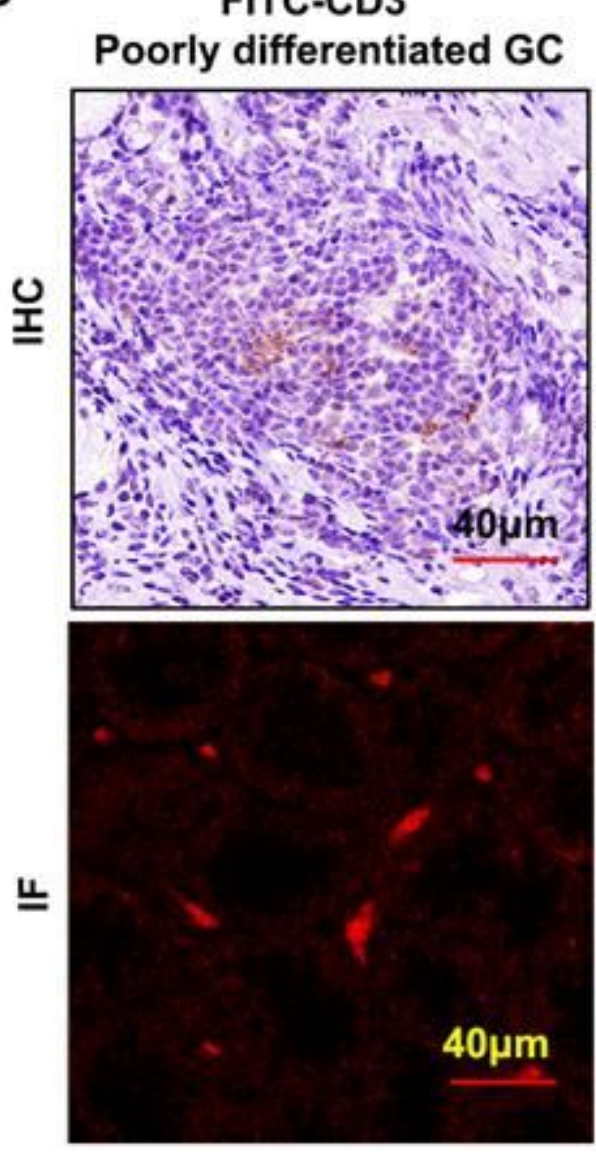

Highly differentiated GC

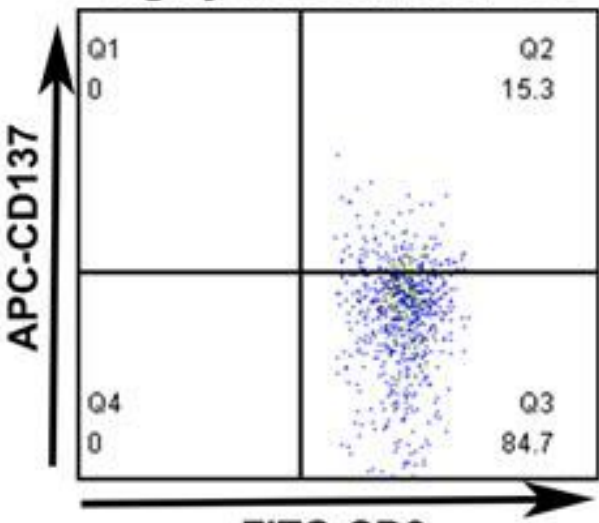

FITC-CD3
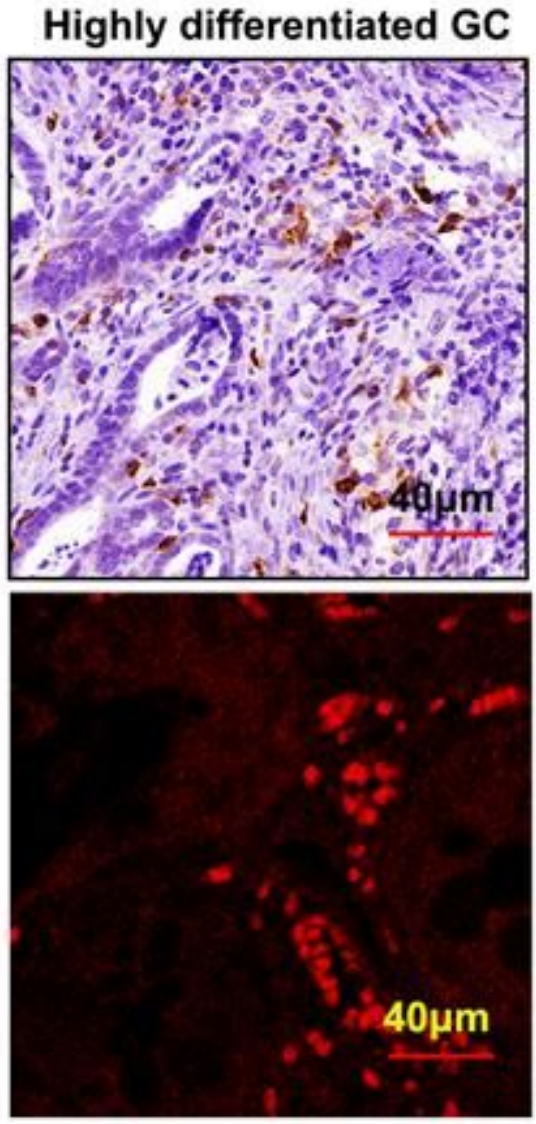

B
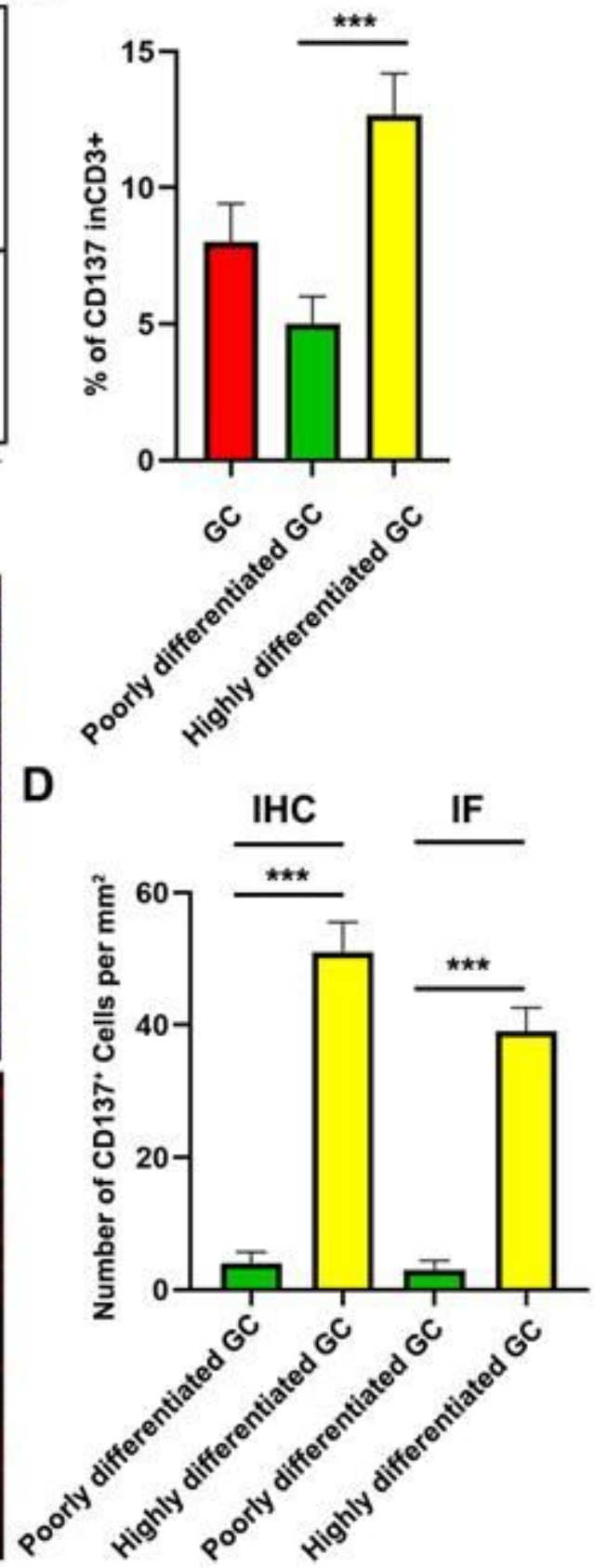

Figure 2

CD137 was highly expressed in TILs of GCs. A, CD137 expression in GCs was examined using flow cytometry. B, Statistical analysis of CD137 expression in different differentiations of GCs. C, CD137 expression in GCs was measured using IHC and IF. D, Statistical analysis of CD137 expression in different differentiations of GCs 

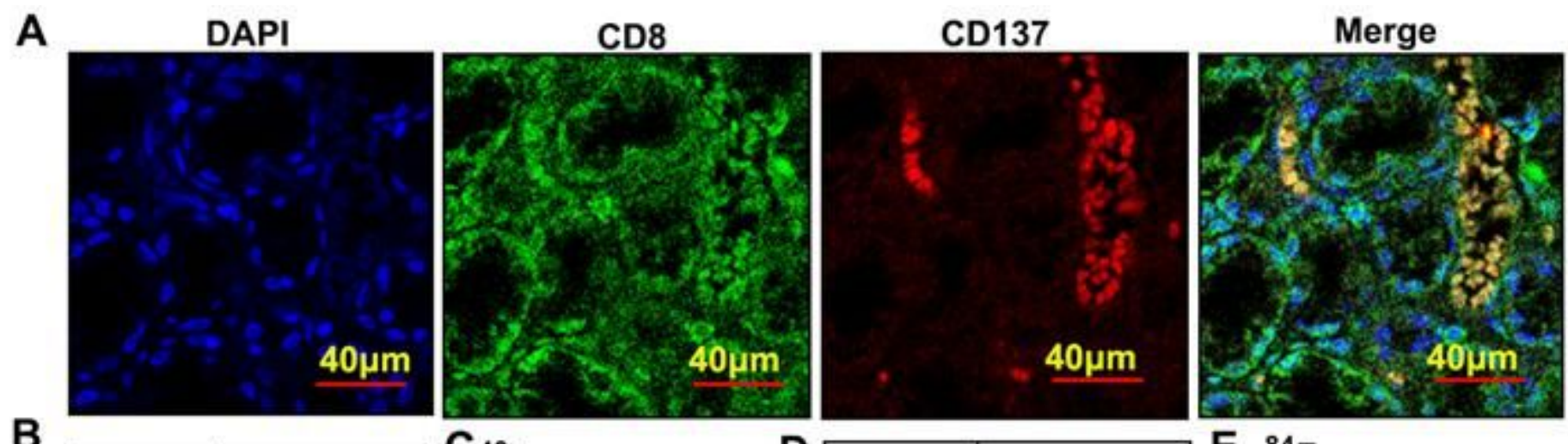

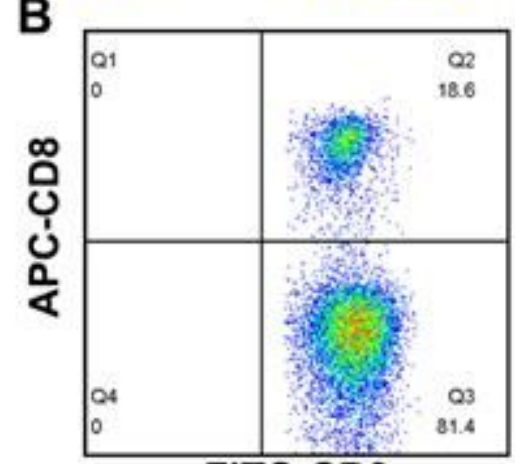

FITC-CD3

$\mathbf{F}$

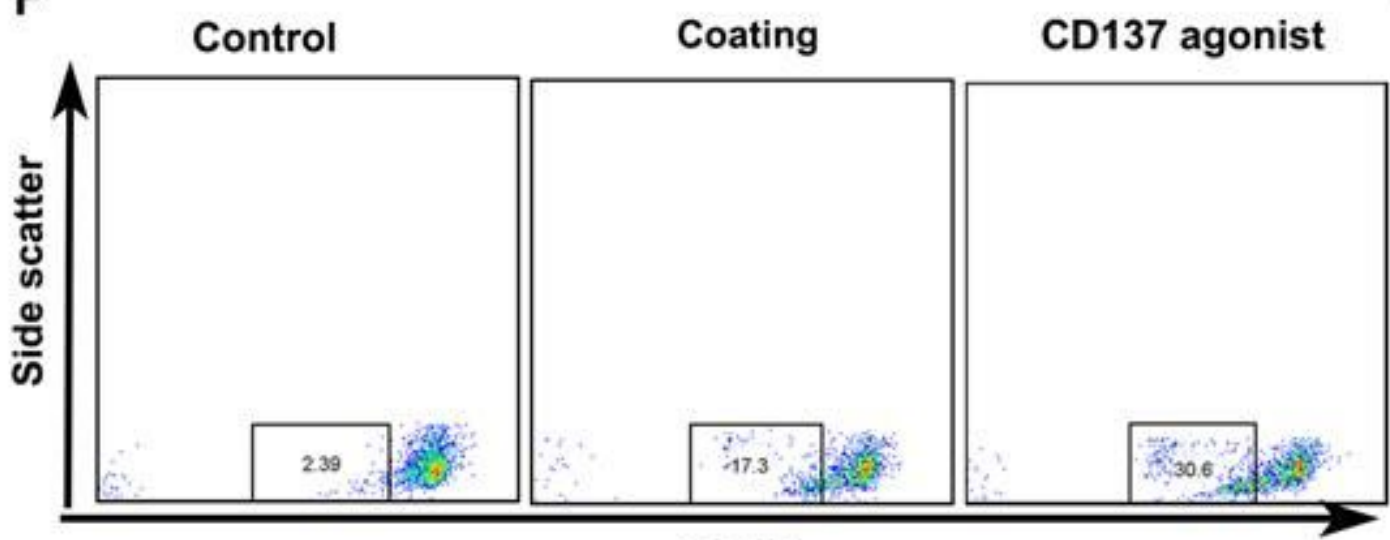

CFSE

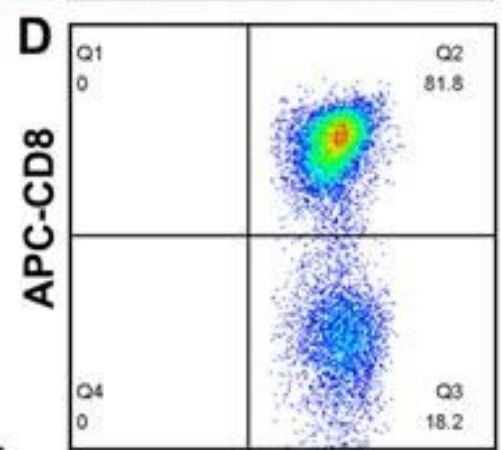

FITC-CD3

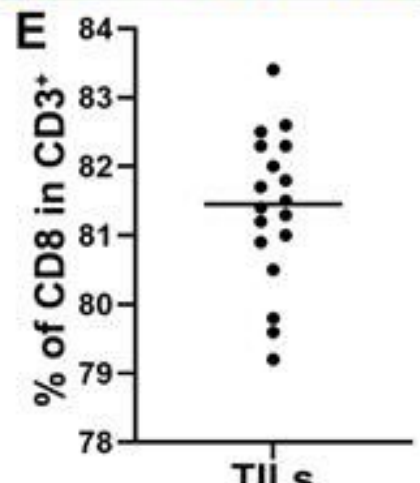

G

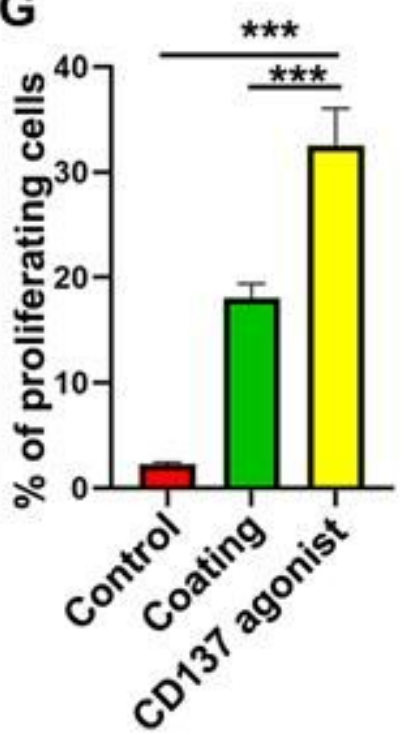

Figure 3

CD137 was primarily expressed on CD8+ T cells and a CD137 agonist enhanced CD8+ T cell proliferation. A, CD137 expression was examined using IF. B, The ratio of CD8 in CD3 before isolation. C, The ratio of CD8 in CD3 of an individual patient before isolation is presented. D, The ratio of CD8 in CD3 after isolation. E, Ratio of CD8 in CD3 of an individual patient after isolation is presented. F, CD8+ T cell proliferation in response to a CD137 agonist. G, Values are means with standard error of the mean. 
A

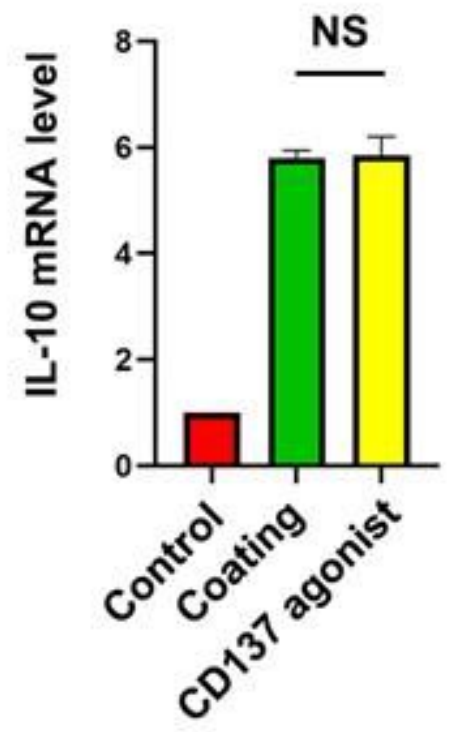

C

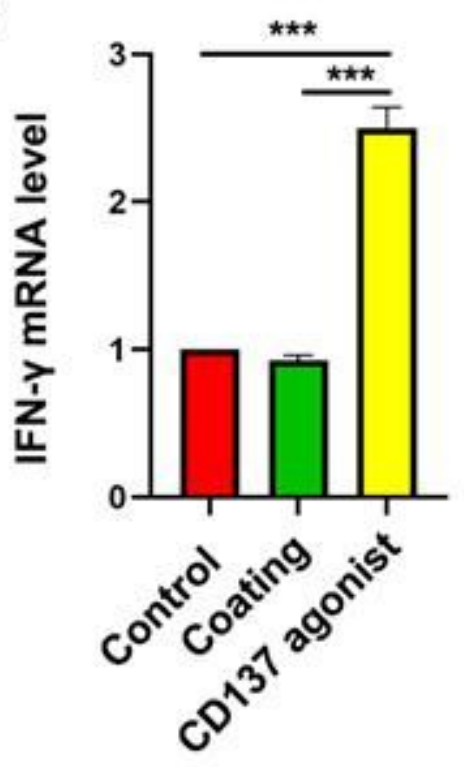

B
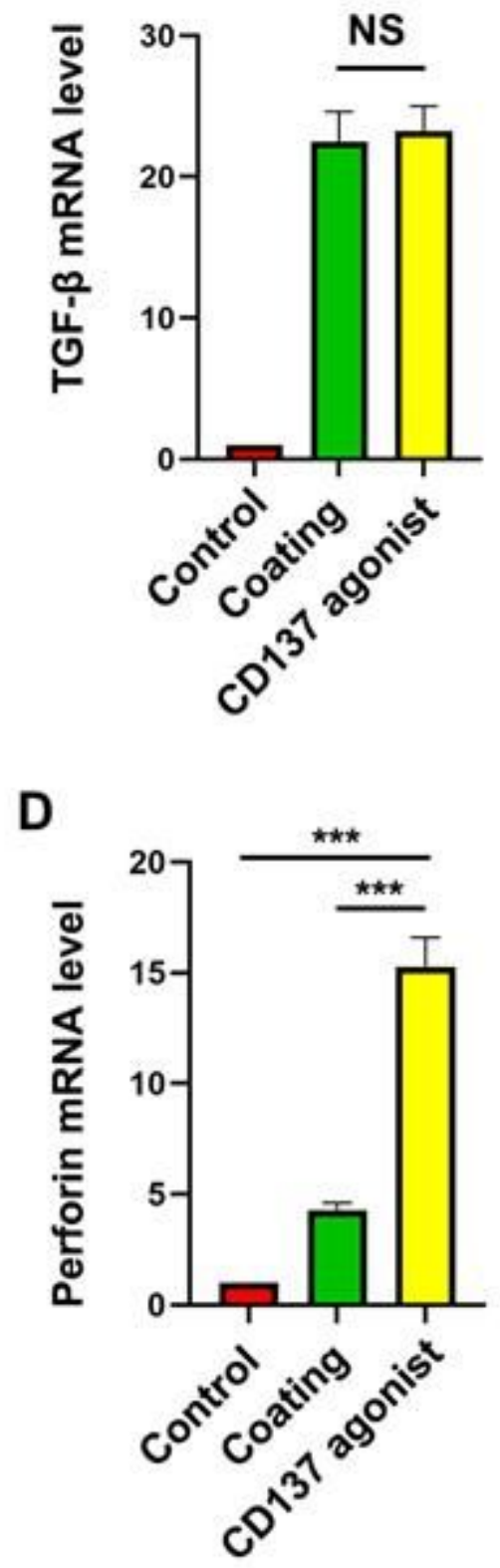

$\mathbf{E}$

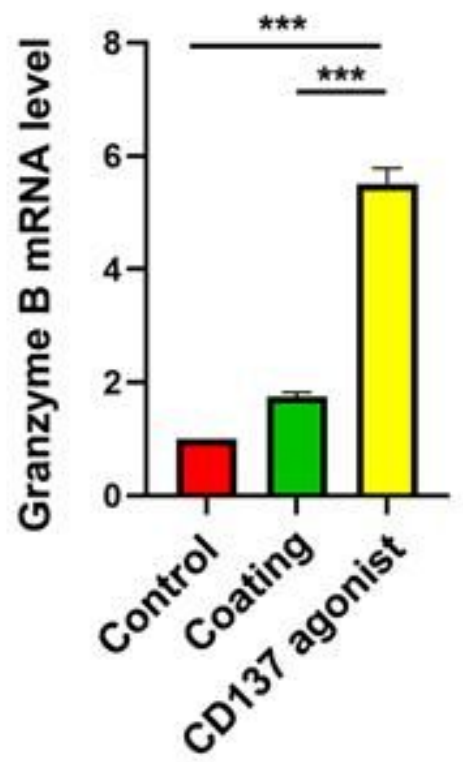

Figure 4

Functions of a CD137 agonist in the PBMCs of GC patients. A, IL-10 detected using real-time PCR. B, TGF$\beta$ detected using real-time PCR. C, IFN- $\gamma$ detected using real-time PCR. D, Perforin detected using real-time PCR. E, Granzyme B detected using real-time PCR. NS=no significance. 


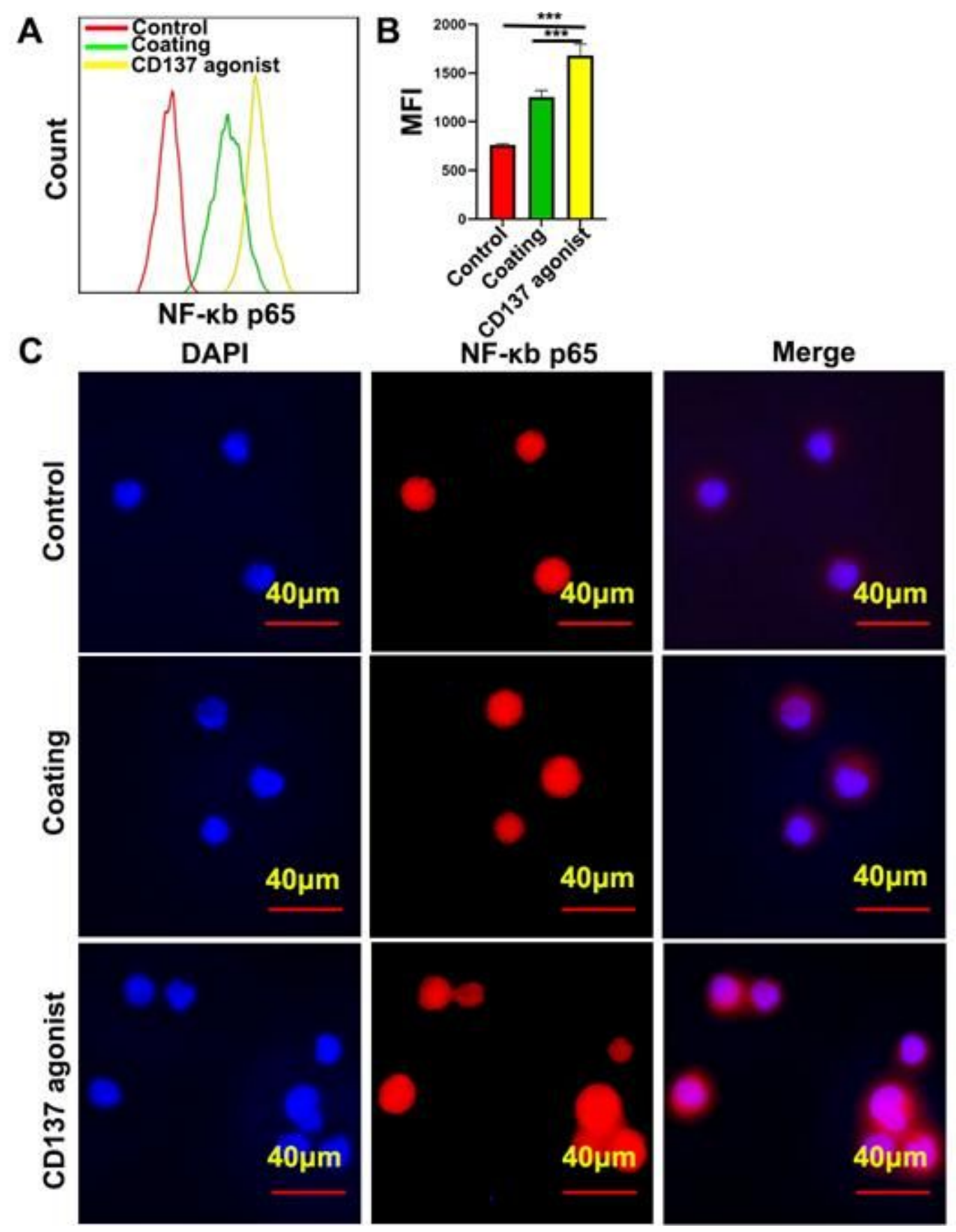

Figure 5

P65 expression and nuclear translocation were increased by the targeting of CD137. A, The effect of a CD137 agonist on p65 expression was measured using flow cytometry. B, Values are means with standard error of the mean. C, The influence of a CD137 agonist on p65 translocation was detected using IF. 
A

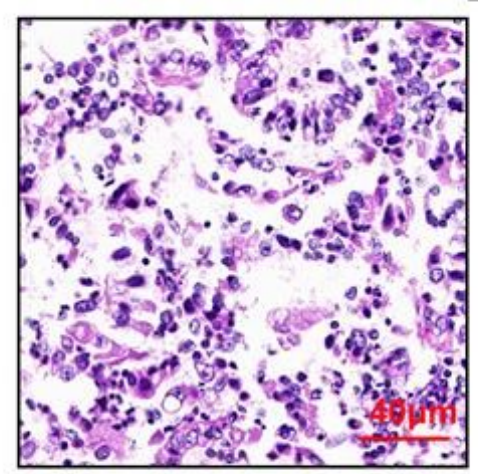

HE
B

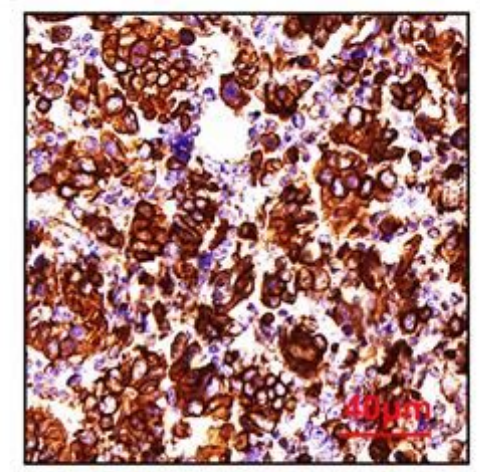

Cytokeratin
E

Control

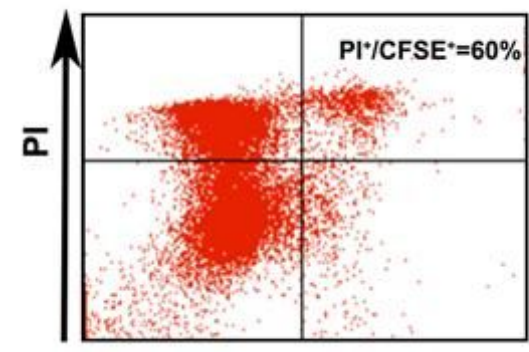

Coating

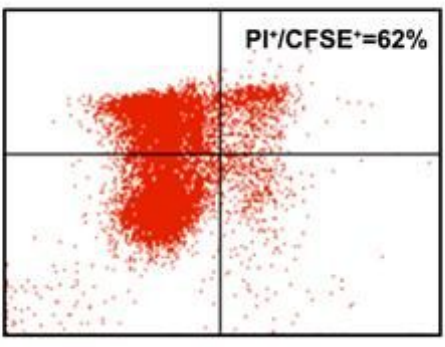

CFSE
C

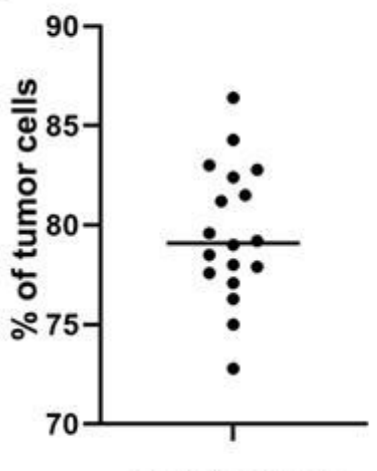

Isolated cells
D

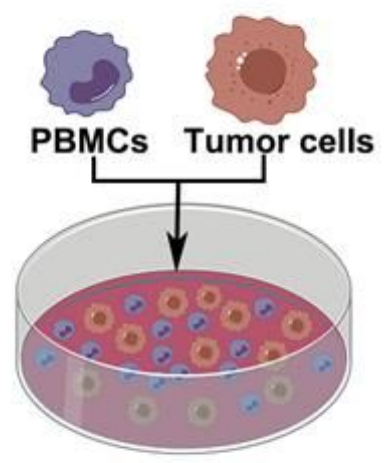

F

CD137 agonist
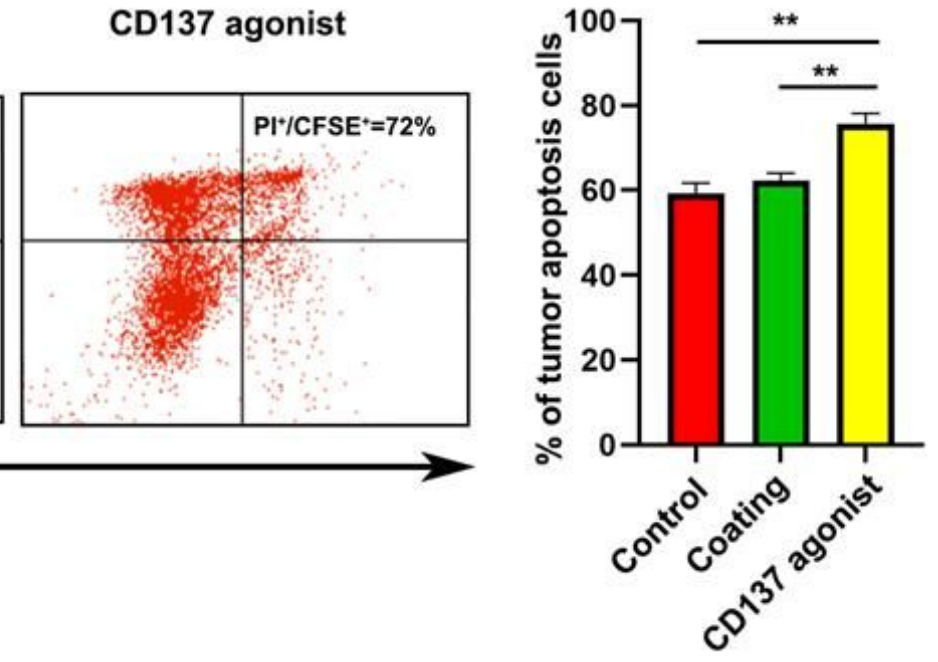

Figure 6

A CD137 agonist significantly induced apoptosis in primary GC cells. A, The purity of isolated tumor cells was detected using $\mathrm{HE}$ staining. $\mathrm{B}, \mathrm{IHC}$ confirmed the purity of isolated tumor cells. C, The purity of an individual patient after tumor isolation is presented. Values are means with standard error of the mean. D, Apoptosis of primary GC cells was detected using flow cytometry. E, Quantification of primary GC cell apoptosis. Values are means with standard error of the mean. 


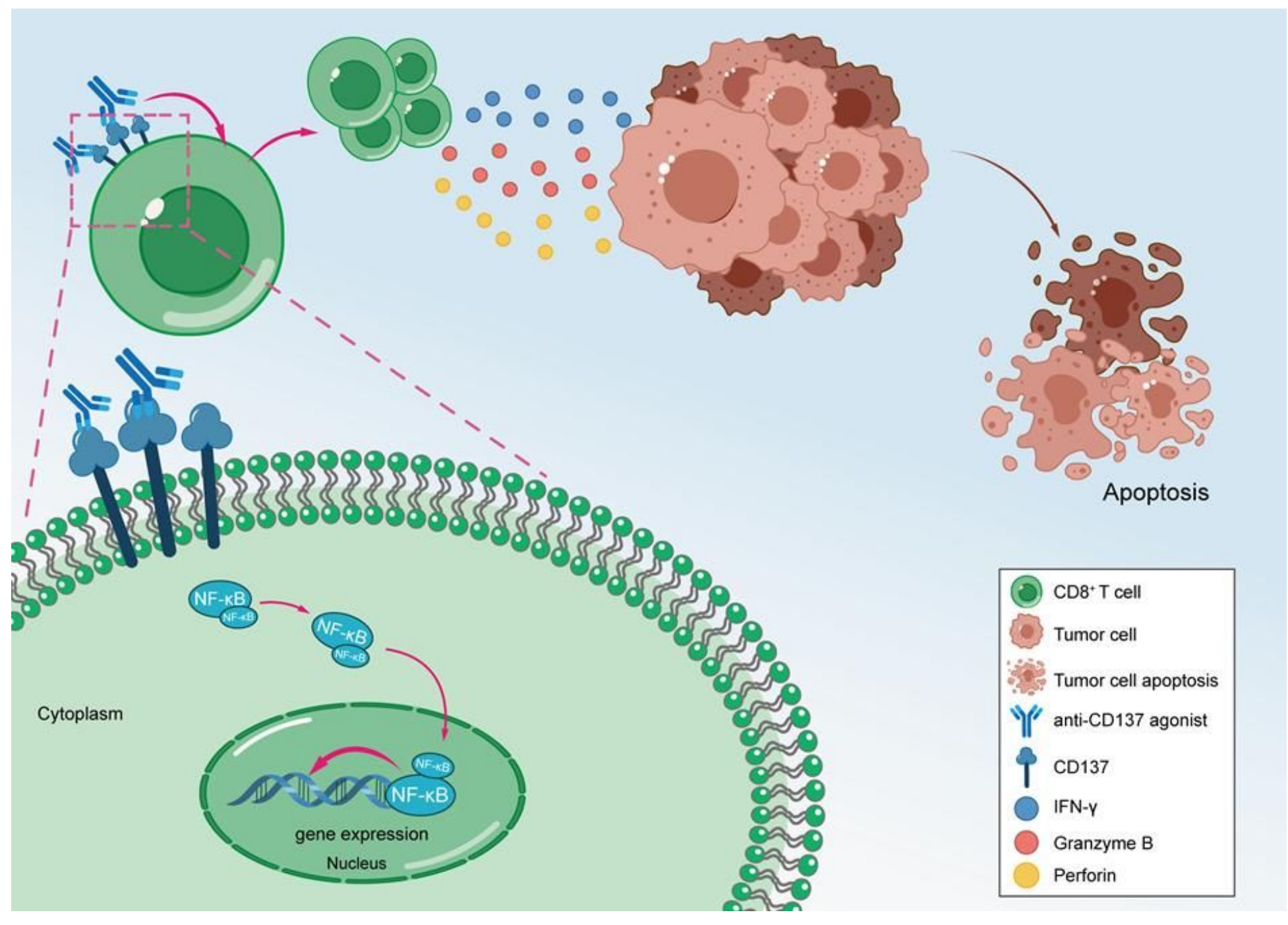

Figure 7

Schematic diagram of a CD137 agonist in inducing GC apoptosis via enhancing CD8+ T cell functions. 